\title{
Basel III and the Strengthening of Capital Requirement: The obstinacy in mistake or why "it" will happen again ${ }^{1}$
}

\author{
Bernard Vallageas ${ }^{2,3}$ \\ Collège d'Etudes Interdisciplinaires, Faculté Jean-Monnet, Université Paris- \\ Sud, France
}

\begin{abstract}
Since the financial liberalisation of the 80 's, the Basel committee on Banking Supervision wants to strengthen banks' capital and other stable funding with the purpose of increasing banks' financial security, as stable funding increases the security of the non-financial business sector. But bank capital has nothing to do with bank security and with money creation. It is shown, instead, that increasing banks' stable funding entails a decreasing of the stable funding for the rest of the economy and securitization. Thus this strengthening is harmful and the way for the financial sector to work in the interest of the economy is to separate deposit banks and other financial institutions, to strengthen banks' control and to recognize they do not need capital, and therefore no owners.
\end{abstract}

\section{Résumé}

Depuis la libéralisation des années 80, le comité de Bâle veut renforcer le capital des banques et leurs autres ressources permanentes dans le but d'accroître leur sécurité financière, tout comme l'accroissement de leurs capitaux permanents renforce la sécurité financière des entreprises industrielles. Mais le capital d'une banque n'a aucun rôle dans sa sécurité ni dans la création monétaire. Au contraire nous montrons que l'accroissement des capitaux permanents des banques entraîne une décroissance de ceux des entreprises industrielles et de la titrisation. Aussi ce renforcement est nuisible et pour que le secteur financier travaille dans l'intérêt de toute l'économie, il faut séparer les banques de dépôt des autres institutions financières, renforcer le contrôle des banques et reconnaître qu'elles n'ont pas besoin de capital et donc pas besoin de propriétaires.

JEL: E42 E44 E58 G32 G38

Key words: Bank capital, bank ratios, deposit banks, Basel accord

\section{Introduction}

On September 6, 2009, after the 2007-2009 financial crisis, the deepest since 1929, the Group of Central Bank Governors and Heads of Supervision, chaired by the French president of the European Central Bank, Jean-Claude Trichet, met at Basel in the headquarters of the Bank for International Settlements (BIS 2009b). The Group decided to strengthen the capital requirement of banks. However, as Bardoloi (2003)

\footnotetext{
${ }^{1}$ Cf. Minsky 1982.

2 Preliminary drafts of this paper have been presented at the workshop on the crisis organised by the Association pour le Développement des Etudes Keynésiennes and the Collège d'Etudes Interdisciplinaires at Université Paris-Sud, on December, 16, 2009, at the international conference "Questioning the Crisis and Prospects for Change" organised by the Action COST IS0902, Systemic Risks, Financial Crises and Credit, with support of the Centre d'Economie de l'Université Paris-Nord and of the Laboratoire d'Economie Dyonisien (Université Paris 8) on October 27, 2010 at the Maison des Sciences de l'Homme Paris-Nord, at the seminar organized by the Centre Lillois d'Etudes et de Recherches Sociologiques et Economiques (Université des Sciences et Techniques de Lille) on March 24, 2012, and at the international conference "Political Economy and the Outlook for Capitalism" organized by the Association for Heterodox Economics, the International Initiative for Promoting Political Economy, the French Association of Political Economy and the Association pour le Développement de l'Economie Keynésienne at Université Paris I on July 5- 7, 2012.. The author thanks the participants in these conferences for their observations and Mario Seccareccia for his English rewriting. He takes sole responsibility for any remaining mistakes.

3 This paper was first written for the book Monetary economies of production: banking and financial circuits and the role of the State. Essays in honour of Alain Parguez, Rochon, L.-P. and Seccareccia, M. (eds), Cheltenham: Edward Elgar. We wish to acknowledge the editors and the publisher for permission to print it here.
} 
affirmed, that is only new wine in an old bottle. The old bottle (called "Basel I"), the institution of capital requirement for banks, had been invented in July 1988 (BIS 1998, BIS 2009a), some months after the October 1987 crash, by the group of central bank governors; and the new wine (called "Basel III") is the strengthening of this requirement: more quality, consistency and transparency of the tier 1 capital, capital conservation measures such as constraints on capital distributions, increase of the leverage ratio, introduction of a counter-cyclical capital buffer... After the September 6, 2009 meeting, the Basel Committee on Banking Supervision published two consultative documents (BIS 2009c,d) on the improvement of the capital requirement and launched a consultation process of the financial actors. In December 2010, it published two documents (BIS 2010a,b), the new wine, to implement this improvement.

All of these measures concern banks' capital, but before 1988 no one worried about banks' capital, and nevertheless there had occurred no major crisis since the Great Depression. Curiously the adoption of capital requirements had taken place at the same time as the liberalisation of the financial system and, yet, despite their adoption, they did not prevent financial crises, particularly the major 2007-2009 crisis. Moreover, the strengthening of these capital requirements was part of the bank rescue package of 2008 (Vallageas 2009).

The idea we want to develop in this paper is that capital requirements may be a good tool for nonfinancial business enterprises, but they are not appropriate for banks, and, if excessive, these requirements may even prevent the banking system from working correctly and could create dysfunctions in the real economy. Most economists, even heterodox colleagues4, consider that the strengthening of bank capital is a good thing, even if other regulations are necessary, and that, in any case, it cannot do wrong. Our idea is that it does do wrong. The decline of Keynesianism since the 80's has reinforced the neoclassical idea that money is neutral, that everything works as if money did not exist, so that banks are financial intermediaries that borrow money, but do not create it. Therefore the distinction between deposit banks, normally described as commercial banks, which create money, and other financial entities, which do not, has been abolished (e.g. in France by the law of January 24, 1984 and in the U.S. by the Gramm-Leach-Bliley Act of November 12, 1999 reforming the Glass Steagall Act of 1933). Finally banks are considered like industrial firms, they must be free, they ought not to be regulated, and they must have capital. As it is for industrial enterprises, capital would be tool to ensure security, and thus it should be reinforced. But that is wrong; banks do not behave like industrial firms.

The advocates of capital requirement have forgotten that deposit banks create money and, hence, in a first section, we will review how these banks create money and show why capital has no role in that creation.

In a second section we will show that two new ratios introduced as the new wine in the two December 2010 documents (BIS 2010a,b) are a very bad wine since they reveal an absolute misunderstanding of the way the banking system works and a total confusion between deposit banks and other financial entities. The adoption by financial entities of these two ratios, conceived originally for non-financial business firms, will worsen the financial situation of these latter firms. Their adoption will also give rise to an increase of securitization which will entail dysfunctions. Thus the strengthening of bank capital will do wrong.

In a third and last section, we shall consider where bank capital comes from and what is its purpose, since it is neither for money creation nor for deposit security.

In the conclusion, we will outline some ideas for a reform of deposit banks.

\section{Deposit banks use reserves of central bank money, and not their capital, to create money}

Money creation is neither considered by orthodox theory nor by the originators of capital requirements. These original advocates only considered bank capital because they thought that it secures bank liabilities, just as industrial firms' capital secures industrial firms' liabilities. But, contrary to this belief, bank capital does not secure bank liabilities. To understand this point we must study a bank balance sheet and concentrate on the specificity of banks in the creation of money. Indeed only deposit banks, i.e. banks that receive demand

${ }^{4}$ With the notable exception of Toporowski (2009) 
deposits, create money, and we shall focus on these institutions. First we shall compare deposit banks' balance sheets and industrial firms' balance sheets, and then we shall study how banks create money in a metallic money regime and in a modern regime of non-convertible notes.

\subsection{The balance sheets of an industrial firm and of a deposit bank}

We present (Figure 1) the balance sheet of an industrial firm as it is normally circulated at an annual meeting of shareholders before the allocation of profit that goes toward the payment of dividends. We remind the reader of the meaning of the different items. The capital measures the value of the shareholders' contributions. These contributions are assets, which, whatever their form, money or other, appear in the assets column and whose value is registered for the same amount in the capital account, because of the double-entry system. The reserves measure that part of the assets which are truly owned by the shareholders but which are not included in the value of capital (e.g. the retained earnings). The aggregate of capital and reserves constitutes the shareholders' equity (in red) and measures the part of the assets which truly belongs to the shareholders, the other assets being financed by debts. Therefore, the first function of shareholders' equity (in red) is to finance a part of the assets.

Figure 1 Balance-sheet of an industrial firm before allocation of profit

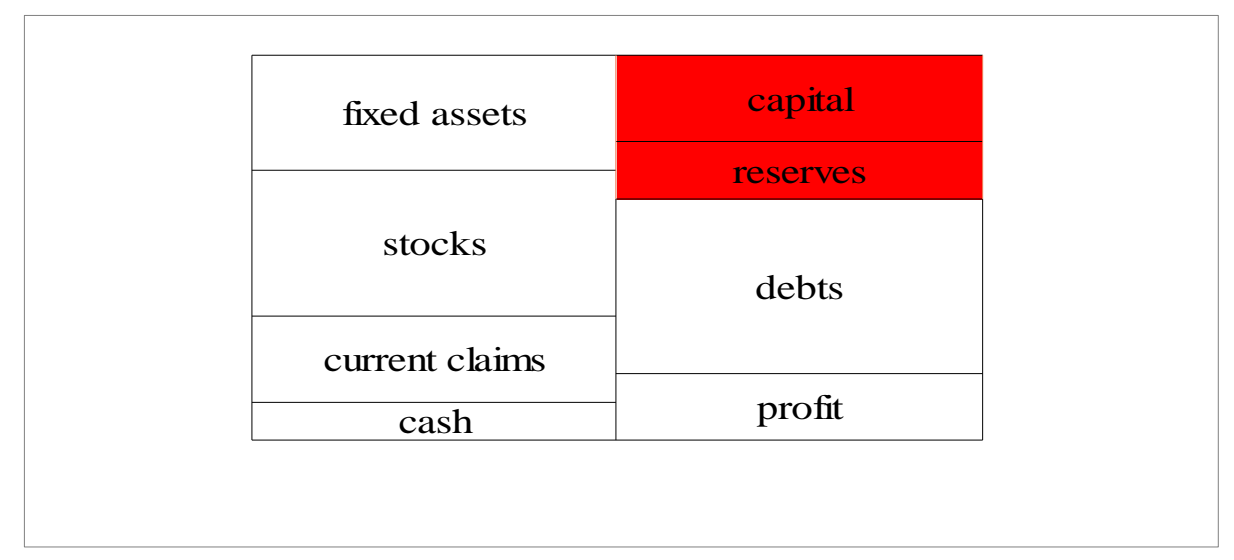

Its second function is to secure the debts, since the creditors can seize the assets belonging to the shareholders. It is this last function, that the proponents of capital requirement want to apply to banks. By doing so they think wrongly that they will secure banks' liabilities.

Indeed, as a bank is legally a firm, its balance sheet looks similar to that of an industrial firm (see Figure 2).

\section{Figure 2 Balance sheet of a deposit bank}

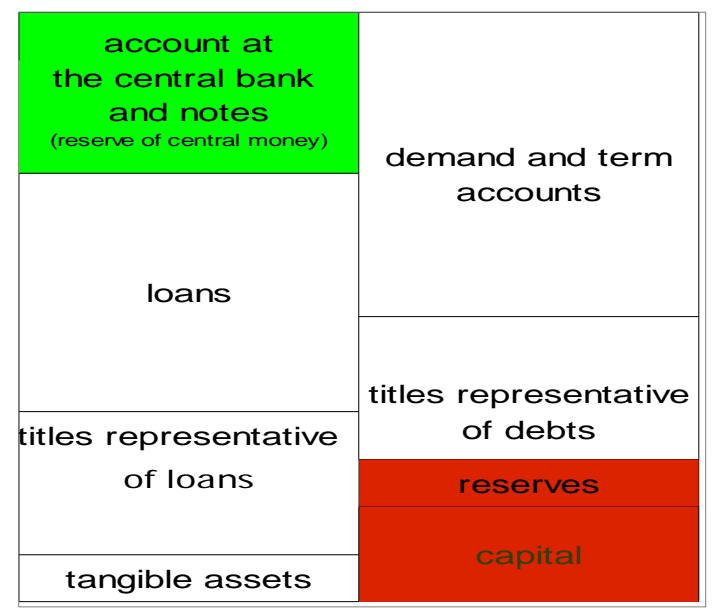


However, it is convention to set it upside down, i.e. equity and tangible assets are written at the bottom. In addition to this difference of presentation, there are two peculiarities: 1 . tangible assets are very small (the only machines that a bank needs are computers and it does not need raw materials); 2 . among the financial assets one must distinguish the account at the central bank (in green) called by monetary economists the reserve of central bank money. This account is not peculiar to banks, since any firm may in principle have an account at the central bank, although it is not common institutionally in Western countries.

So we see that banks have a balance sheet similar to that of other firms and the two peculiarities do not come from law or accounting principles but from the true nature of deposit banks.

It is these two peculiarities that the advocates of banks' capital requirement have neglected to consider, by confusing reserves of central bank money (in green) and reserves in the purely accounting sense (in red). By doing so, they have forgotten the necessity of the central bank.

To develop this point, we must first consider the principle of monetary creation by a deposit bank. We will distinguish two categories of monetary systems: 1 . the metallic currency system; 2 . the modern monetary system in which the central bank is absolutely necessary to allow the interbank payments and settlements.

\subsection{The monetary creation by a deposit bank}

a) Under a metal currency regime

In this system, some people deposit metal (say gold) or bank notes convertible into this metal at the deposit bank (item in green on the balance sheet, Figure 3). This gold or notes are written on the asset side of the balance sheet, but, as they are not the property of the bank, a debt of a same amount (called the initial debt) is written on the liability side. Then, as most deposits are stable, the bank takes the risk to lend more than it has received, and these deposits then appear as supplementary loans and supplementary debts. The deposits to the bank come from ordinary people and not from the central bank. So the system may work only with gold, without notes and a central bank. The initial deposits (in green on Fig. 3) are called reserves by monetary theorists and banks must wait for them before lending. Thus the reserves appear ex ante.

Figure 3 Balance sheet of a deposit bank under a metal currency regime

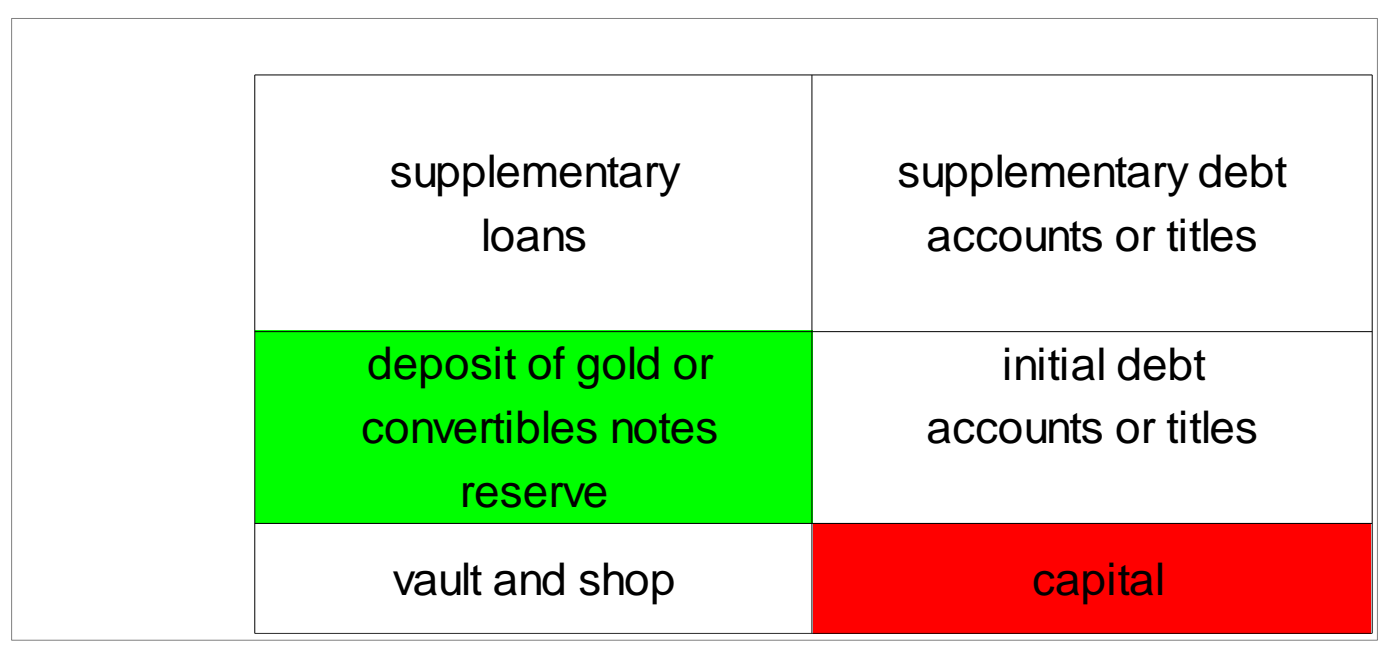

Indeed the bank anticipates that only the $\mathrm{k}^{\text {th }}$ of its creditors (including initial and supplementary creditors) will withdraw gold or notes. So the total debt of the bank may multiply to $k$ times the initial deposits. If more creditors want to withdraw their deposit, the bank will fail. So the ratio that matters is $k$, the credit or deposit multiplier. The bank's capital does not appear in this ratio. Nevertheless the bank balance sheet includes an item called capital, which measures the contribution of the bank's owners. With this contribution, the bank has bought some tangible assets (say, a shop and a vault to keep gold or the notes). These tangible assets 


\section{World Economic Review}

may be seized when the bank fails, but their value compared to that of their deposits is low and no classical theory of monetary creation has considered it: there is no place for a capital ratio in the anti-bullionist or Banking School literature and neither is to be found in the theory of monetary creation by the deposit banks, which developed during the inter-war period.

\section{b) Under the modern system of a non-convertible central money.}

It is the universal system nowadays. There is no more metal, and notes are non-convertible and are issued by a central bank. The standard balance sheet of a deposit bank is depicted in Figure 2. Notes and accounts at the central bank constitute the central bank money. That part of these notes and accounts which belongs to the deposit banks (in green on Figure 2) are called reserves by monetary theorists. Central bank money appears in two ways:

(A) by means of credit advances from the central bank to the State, but these advances may be forbidden, as in Euroland;

(B) by advances from the central bank to deposit banks. Indeed banks borrow central bank money either for the interbank payments or because their customers want notes.

So the reserves arise in two ways:

(1) either the State spends central bank money for the services of a supplier or an employee, who holds it in his own deposit bank;

(2) or the deposit bank borrows from the central bank.

We may notice that the increase in reserves entailed by the first method is not the true property of the bank, since the bank keeps these funds for the account of its customer, the State's supplier or employee. So the first method resembles the old system when the customer brought gold to the bank. But this method works only for the State's suppliers and employees and it cannot possibly work if the State is not allowed to borrow from the central bank as in Euroland.

With the second method, the deposit bank borrows from the central bank only when it is obliged, i.e. when people want notes or when the bank needs central money for interbank settlements. These situations occur only when banks have already lent, so the reserves appear ex post and the concept of credit/deposit multiplier metamorphosizes into that of credit divisor.

\section{c) Common characteristics.}

In both systems, the ratio that matters is a link between the reserves (in green) and the money created, therefore the item "capital" (in red) of the balance sheet does not appear. In both systems, the reserves do not belong to the banks but are borrowed either from a depositor (a depositor of gold in the gold regime and as a result of a State's supplier or employee depositing central bank money in the modern system) or from the central bank in the modern system.

In fact the separation between the two regimes is not absolute, since, for instance, during the $19^{\text {th }}$ century deposit banks might use the discount window of the central bank to get central bank money for loans that they had already made. In which case, reserves might be ex post. But what matters is that in no case bank's capital is considered.

Hence, despite the uselessness of capital for money creation and for the security of banks deposits, the Basel committee wants to strengthen capital requirements in implementing Basel III.

\section{The new ratios implemented by Basel III denote a non-comprehension of the way the banking system works, they will entail more securitization and so will be counterproductive}

\subsection{The principal ratios of the Basel III documents}

The documents published by the Basel Committee on Banking Supervision, as well the two consultative of December 2009 (BIS 2009c,d) and the two final of December 2010 (BIS 2010a,b) continue to strengthen the capital ratio invented with Basel I in July 1988 and they introduce two new ratios, the Liquidity Coverage Ratio (LCR) and the Net Stable Funding Ratio (NSFR).

The strengthening of capital ratio reflects the continuation of Basel I and II (BIS 1998 and 2009a). 


\section{World Economic Review}

Basel I has introduced an $8 \%$ ratio of capital on assets weighted according their nature called the "Cooke ratio" and Basel II has improved this ratio, now called the "McDonough ratio" by introducing the riskweighting of assets. Basel III (BIS 2010a,b) now wants to add a capital conservation buffer, that is an increase of the ratio in periods of good conjuncture, which will reach $2.5 \%$ on January 2019 . A countercyclical buffer, which could rise to $2.5 \%$, could be added in period of excess credit growth and the committee is working on the possibility to have larger requirements for systemically important banks. Moreover, Basel III introduces a simple leverage ratio that is not risk-weighted.

Indeed one can wonder what the precise justification of these figures is. There is, for instance, no explanation of the initial ratio of $8 \%$ and it seems that the Basel committee wants to increase it without limit. Nevertheless the newly introduced Basel III ratio, the NSFR, seems to justify the importance of bank capital, but it is an application of the classical financial analysis originally conceived for industrial firms and which cannot be applied to banks.

\subsection{The new ratios LCR and NSFR are transposed from the financial analysis of industrial firms and, at first glance, do not look arbitrary}

Both ratios come from a simple idea developed for industrial firms: the assets are used to pay the financial commitments written on the liabilities side of the balance sheet. So the payment of each commitment must be warranted by an asset of the same maturity or shorter: roughly the short-term liabilities must be covered by short-term assets. The Basel III accords (BIS 2010a,b) suggest (we write "suggest" since the Basel accords are not compulsory before being enacted by each jurisdiction) to take stock of all the commitments to be paid in the next 30 days and to verify that they are covered by inflows coming from the assets during the same period. The stock of assets that are supposed to assure inflows in the next 30 days is called "Stock of High Quality Liquid Assets" (SHQLA). The LCR is the ratio of this stock divided by the "total Net Cash Outflows over the Next 30 calendar Days" (NCON30D). The ratio must be at least 1 ,

$$
\text { i.e. } L C R=\frac{\text { SHQLA }}{\text { NCON30D }}>1 \text {. }
$$

On the other hand, the stable funds (called "Available Amount of Stable Funding" (AASF) by the Basel documents (BIS 2009b, 2010a,b)), that is shareholders' equity and liabilities of which maturity is at least one year, may be covered by stable assets (called "Required Amount of Stable Funding" (RASF)), i.e. assets of which maturity may be longer than a year. On the basis of this, the Basel III accord suggests that the NSFR, of which the numerator is AASF and the denominator RASF, be at least 1 ,

$$
\text { i.e. NSFR }=\frac{\text { AASF }}{\text { RASF }}>1 \text {. }
$$

This new ratio seems to justify a ratio for the capital requirement. If the assets of maturity of one year or more are $x \%$ of all the assets, the funding of one year or more, i.e. the stable funding, must be $x \%$ of the whole funding. That gives a ratio of stable funding which is not arbitrary, while the ratio of $8 \%$, as well as the ratio of the conservation buffer, are arbitrary.

We may notice that the Basel III documents (BIS 2009c,d, 2010a,b)) say nothing about assets and liabilities of which maturity is medium, i.e. included between 30 days and one year.

If both ratios are satisfied, the bank's balance sheet could be as shown on figure 4 .

Both ratios may be criticised from two points of view: (a) from an internal point of view and (b) from an external point of view.

(a) From an internal point of view, we may show that even if these ratios were correct in their principle, they would be inefficient, which means they would not do wrong, but they would be only inefficient, in which case they must be complemented by other measures.

(b) From an external point of view, we will show that these ratios denote that their policy supporters have not understood how banks work, and what their place in the economy is. Indeed the implementation of the ratios will worsen the financial situation of industrial firms. Moreover banks will increase securitization and such policy thus will be counterproductive. Consequently, these ratios could do harm. 
Figure 4 Balance sheet of a bank showing is financial situation

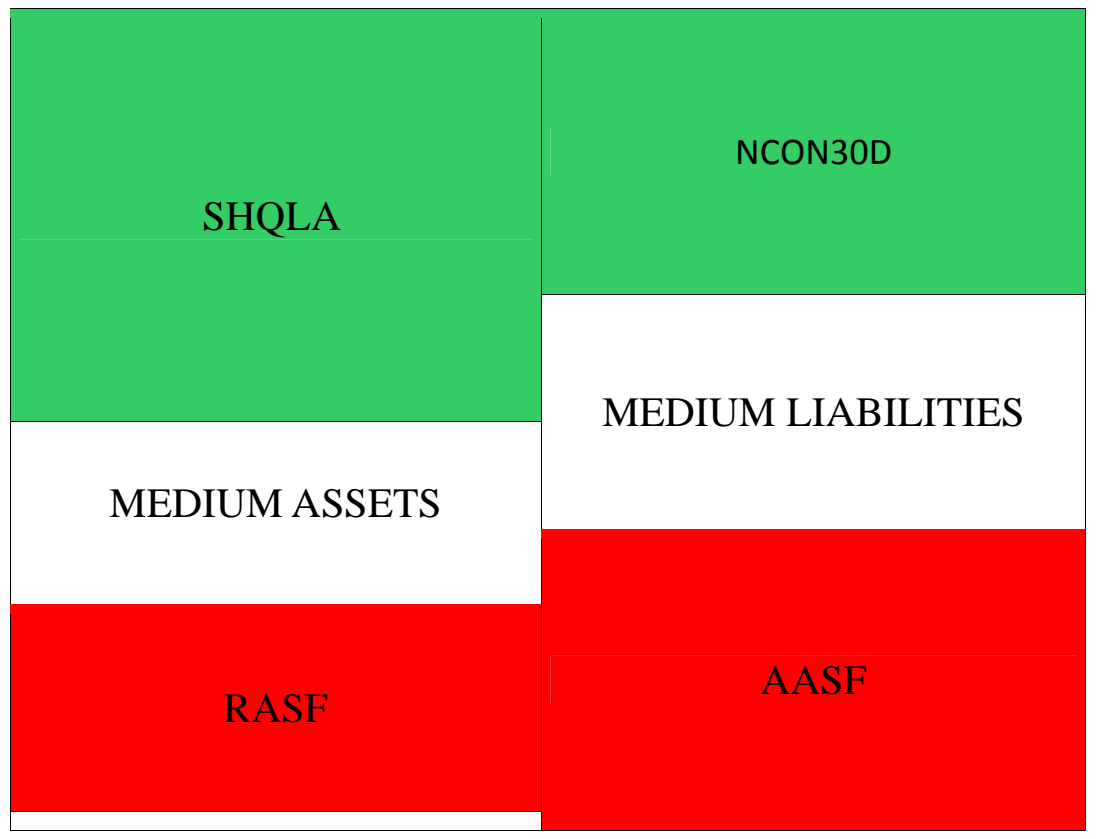

\section{Even if the LCR and NSFR were well conceived, they would be inefficient}

Even if both ratios were easy to conceive and appropriate, their implementation would be much more delicate. Now one must define exactly what must be included in the numerator and denominator of each ratio. The Basel documents (BIS 2010a) give instructions to calculate these elements, but the instructions turn out to be arbitrary. First let us consider the assets that constitute the SHQLA, i.e. the numerator of the LCR. They are divided into "Level 1" and "Level 2" assets with a maximum of 40\% of "Level 2" (BIS 2010a, p. 7). The "Level 1" assets are the assets on public entities (States, central banks, international organizations...), the "Level 2" assets are those issued by private entities. A minimum haircut of $15 \%$ has to be applied to each "Level 2" asset. The figures of $40 \%$ and $15 \%$ are completely arbitrary and, as L. Randall Wray (2006) has already said for Basel II, these rules are only "rules of thumb that guide good banking practice".

The same can be said about NCON30D, the denominator of the LCR. The way to calculate it is outlined below (BIS 2010a, p. 12):

"The term net cash outflows is defined as the total expected cash outflows minus total expected cash inflows in the specified stress scenario for the subsequent 30 calendar days. Total expected cash outflows are calculated by multiplying the outstanding balances of various categories or types of liabilities and off-balance sheet commitments by the rate at which they are expected to run off or to be drawn down. Total expected cash inflows are calculated by multiplying the outstanding balances of various categories of contractual receivables by the rate at which they are expected to flow in under the scenario up to an aggregate cap of $75 \%$ of total expected cash outflows." (Emphasis added)

One can wonder why it is necessary to limit the cash inflows and why this limit must be of $75 \%$ of the outflows and not a different figure. The rates at which the unsecured liabilities are expected to run off are specified (BIS 2010a, pp. 12-17) and go from 5\% for deposits "from natural persons covered by an insurance 
and for which the depositors have an established relationship with the bank" to 100\% for "unsecured wholesale funding provided by legal entity customers" through $25 \%$ for "unsecured wholesale funding with operational relationships". The rates are arbitrary and the classification remains largely subjective. For secured liabilities, derivatives and inflows, the document gives also rates and classifications which are equally arbitrary and subjective.

Let us consider AASF, i.e. the numerator of the NSFR. The Available Stable Funding compounds not only true permanent funding but also deposits, even if they have a maturity less than one year, to the extent that a part of them is expected to be stable. Hence, each liability is affected by an ASF factor depending on its expected degree of stability. These factors are given in a table (BIS 2010a, p. 27). All the true permanent funds, i.e. shareholder's equity (as defined in our section 1 and which appear under the names of "tier 1" and "tier 2") and the liabilities with a maturity of one year or more have an ASF factor of $100 \%$, while deposits for less than one year have a lower ASF factor. Of course there is a relation between the outflows of the deposits in the next 30 days as considered for the LCR and their stability for one year or more as considered for the NSFR, and what we have said about the subjectivity of the classification and the arbitrariness of the rates remains, even if the rates are now called ASF factors.

As for the RASF, i.e. the denominator of the NSFR, it excludes not only the financial assets with a maturity less than one year, but also assets with a maturity of one year or more (called "marketable assets") to the extent that there exists a market that allows to selling them before one year. Hence, the RASF includes all the assets with a maturity of one year or more, but it affects them with a "RSF factor" going from $100 \%$ for the non marketable ones to $5 \%$ for the marketable assets issued by public institutions. Of course the liquidity of the market, and thus the RSF factor, is very subjective.

To summarize the main problems encountered in the calculation of both ratios, we may say that it is difficult to distinguish stable and unstable deposits, i.e. long-term and short-term liabilities. It is also difficult to distinguish permanent and liquid assets, because of the existence of markets which allow for the sale of assets before their maturity. So ASF and RSF appear arbitrary. These difficulties are very peculiar to banks and make the assimilation of banks' finance to industrial firms' finance inappropriate.

The ratios and factors can only be derived from past experiences: the values suggested by the Basel committee (BIS 2010a) can only be normal values derived from history, even if a security margin is added. If only some banks depart from these normal values, the gaps can be covered by insurance. Unfortunately no insurance may cover a systemic risk, which can only be remedied by an intervention of the lender of last resort, the central bank. If it happened exceptional withdrawals on deposit accounts exceeding their normal values, the only remedy would be a supplementary issue of bank notes, and any dysfunctional behaviour of the money market, as it happened in 2008, would imply an expected increase of the RSF factor and an intervention of the central bank would be necessary.

As these ratios come from the past experiences and are very technical, only the men who have lived these experiences, that is bankers, can establish them. It is very significant that the Basel accords come essentially from the work of bankers. The Basel committee has published the 273 opinions (BIS 2010c) that it has received concerning the consultative documents (BIS 2009c,d). The distribution of these opinions is given in Figure 5.

It appears that $80 \%$ of the opinions have been given by representatives of the financial sector, that is the members of "financial capitalism", and only $6 \%$ by the members of "industrial capitalism", the audit and accounting firms working for both forms of capitalism. The last three groups (supervisors, academics and NGO) are supposed to work for the interests of the whole society, but in fact, a large part of the supervisors, especially from central banks, and even of academics, have strong links with "financial capitalism". Thus "financial capitalism" is over-represented, "industrial capitalism" is highly underrepresented, and the rest of society nearly not represented. 


\section{World Economic Review}

Figure 5: Distribution of the opinions received in the consultative documents

\begin{tabular}{|l|r|}
\hline Banks and banks' professional organisms & $66 \%$ \\
\hline Insurances & $3 \%$ \\
\hline Other financial institutions (exchange entities, counsels...) & $7 \%$ \\
\hline Credit rating agencies & $4 \%$ \\
\hline Sub-total 'financial capitalism" & $80 \%$ \\
\hline Industrial firms and industrial firms' organisms & $6 \%$ \\
\hline Audit and accounting firms & $1 \%$ \\
\hline Supervisors & $6 \%$ \\
\hline Academics & $6 \%$ \\
\hline Non-governmental organizations & $1 \%$ \\
\hline Total & $100 \%$ \\
\hline
\end{tabular}

One must regret that a profession whose behaviour impacts strongly all of society is controlled only by itself with nearly no participation from the rest of society. Of course the Basel documents (BIS 2010a,b) are only suggestions that will be implemented after the legal processes work themselves out in the different jurisdictions, but we may fear that these processes constitute only rubber stamping.

\section{The emphasis on LCR and NSFR reveal a lack of understanding of the place of banks and finance in the economy}

Following the Basel documents (BIS 2010a) the LCR and the NSFR should be greater than one. We can distinguish, which is not done by the Basel committee, the deposit banks, which create money, and the other financial institutions, which do not. On the basis of this, we can show that, for the deposit banks, these ratios cannot be greater than one. On the other hand, the aggregate constituted by all the financial institutions, deposit banks and other, may have a NSFR greater than one, but this would imply that the aggregate constituted by all the other economic agents would have a similar ratio lower than one. This means that a situation for financial institutions that is qualified "good" by the Basel committee would imply a situation considered "bad" by classical financial analysis for the real economy.

\section{a) LCR and NSFR can never be greater than one for deposit banks.}

Financial institutions practice bank operations, among them loans and borrowings, as a normal activity. They have to be licensed and, in general, are not allowed to have other activities. Hence there is a legal distinction between financial and other institutions.

More peculiarly financial institutions are the only entities that are allowed to receive deposits from the public. When they receive demand deposits, or short-term deposits, that result from their loan-making activity, they create money or near money. We shall call deposit banks, or simply banks, the financial institutions that receive these deposits. Indeed most money creation comes from an exchange of debts between a bank and a non-bank entity: the former gives to the latter a bank debt (called loan), while the latter gives to the former an ordinary debt of the same amount. In the books of the bank, this debt exchange is written in two separate accounts: in a loan account on the assets side for the ordinary debt to the bank, and in a deposit account on the liabilities side for the debt from the bank. By its very nature the debt to the bank has a certain maturity: when someone borrows from the bank, it is for any motive (buying, paying a salary, lending to someone else...) and, whatever the motive, it will imply that the money will be given by the borrower to someone else. Therefore the bank will not be reimbursed immediately. At the opposite the debt from the bank has a legal maturity of zero, but, in fact, as the deposit has certain stability, it has a longer effective maturity of which expectation is given by the ASF factor. If there existed only one large bank in the 


\section{World Economic Review}

economy, the effective maturity would be exactly the same as that of the loan, since the deposit would remain in the same bank, even when it would be transferred from one depositor to another. Therefore it would be reimbursed exactly at the same moment as the bank loan.

In our actual world, with several banks, deposits have a zero legal maturity and an effective maturity at most equal to the maturity of the bank loans. So the LCR and the NSFR are at most equal to one, and searching to have these ratios greater than one would entail dysfunctions.

b) If the aggregate constituted by all the financial institutions has a NSFR greater than one, the real economy would be in a "bad" financial situation

Now we consider the aggregate constituted by all the financial institutions and we suppose it has achieved a NSFR greater than one. Since deposit banks have a NSFR less than one, that would imply that simple financial intermediaries would have a larger NFSR to compensate for the lower NSFR of the deposit banks. This NSFR $>1$ for financial institutions will have implications for the real economy, i.e. the other part of the economy. To see what will happen in the real economy, we will suppose the economy is closed, and will refer to Figure 6 representing the two balance sheets of the two aggregates constituted by the financial institutions and by the real economy. To facilitate the comparison we have written the balance sheet of the financial sector in the same sense than for the real sector (i.e. equity and tangible assets on the top).

Within these balance sheets we shall consider only the legal maturities, that is before the effect of the ASF and RSF factors. The titles are all those representing loans of at least one year or shares held by the real economy on the financial institutions. The long-term loans are the loans of one year or more from the financial sector to the real economy corresponding to the borrowings of the real economy. The short-term loans and borrowings are similar but have a maturity less than one year. To simplify our demonstration we have not differentiated medium and short-term loans contrary the Basel documents (Basel 2010a) as shown in Figure 4. The deposits include all the liabilities of maturity less than one year from the financial sector to the real sector. The tangible assets are specific to each sector. The equity on the real sector held by the financial sector is included in the long-term loans from the financial sector to the real sector, while the equity on the financial sector held by the real sector is included in the titles held by the real sector on the financial sector. The loans and borrowings of each sector on itself are eliminated via within sector compensation.

Let us suppose the financial sector is in a "good" financial situation, as it is on Figure 5, i.e. its shortterm borrowings (the deposits) are smaller than their short-term loans and thus the long-term funding is larger than the long-term assets, implying a NSFR greater than one. Therefore, by symmetry, the short-term borrowings of the real sector are smaller than their short-term loans (the deposits), which implies a "bad" financial situation. So the financial situation of the real sector is symmetrical to that of the financial sector, and the search of a "good" financial situation for the financial sector, i.e. a NSFR greater than one, implies a "bad" one, i.e. a NSFR lesser than one, for the real sector.

We may verify this with the use of national accounts. Let us consider the balance sheet of the whole French economy on December 31, 2009 published by the Institut National de la Statistique et des Etudes Economiques (INSEE 2011). As this is an open economy, we must oppose the situation of the French financial institutions to the aggregated situation of the French real economy with the rest of the world and verify that the situation of the former is the exact reverse of that of the latter. As the balance sheet is highly aggregated there is no distinction between long-term and short-term loans, but between loans which are represented by titles (titles other than shares) and those which are not (credits). If we suppose that the titles represent loans of one year or more and the credits shorter loans, we get the Figure 7 in billions of euros. 
Figure 6 Aggregated balance sheets

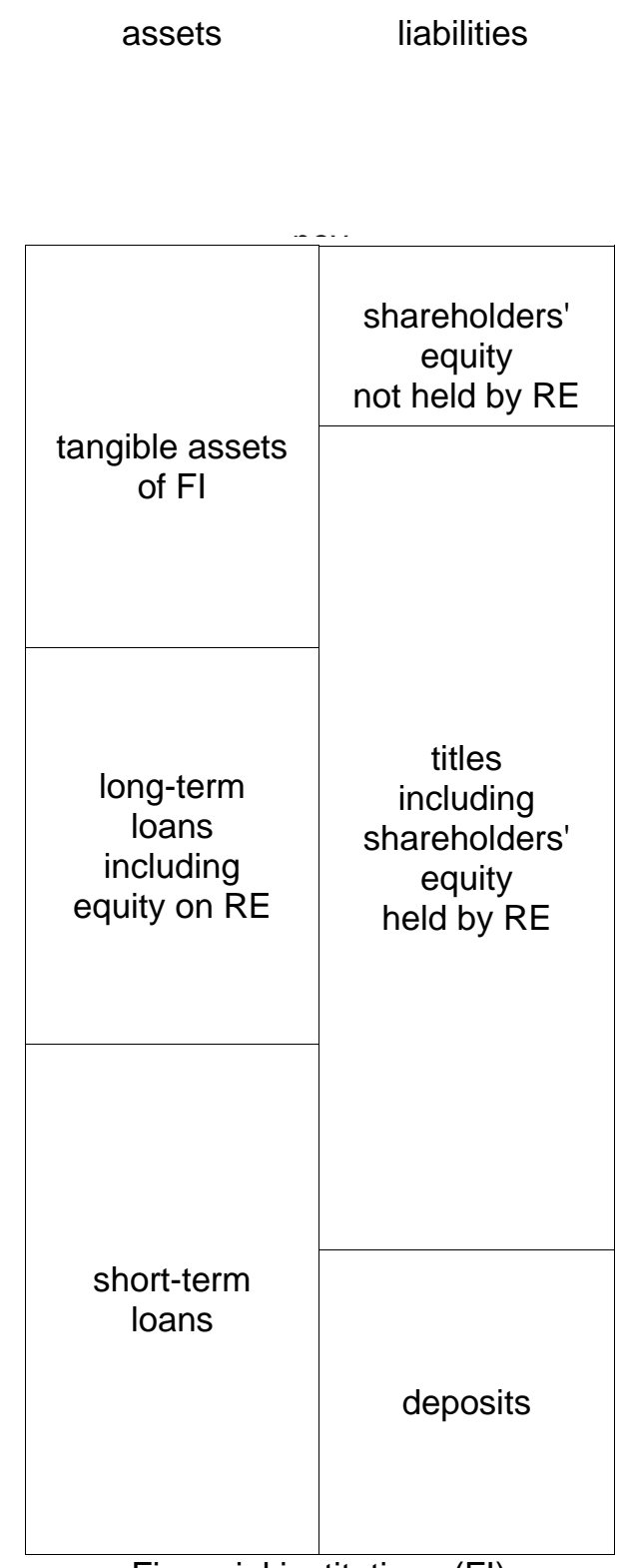

Financial institutions (FI)

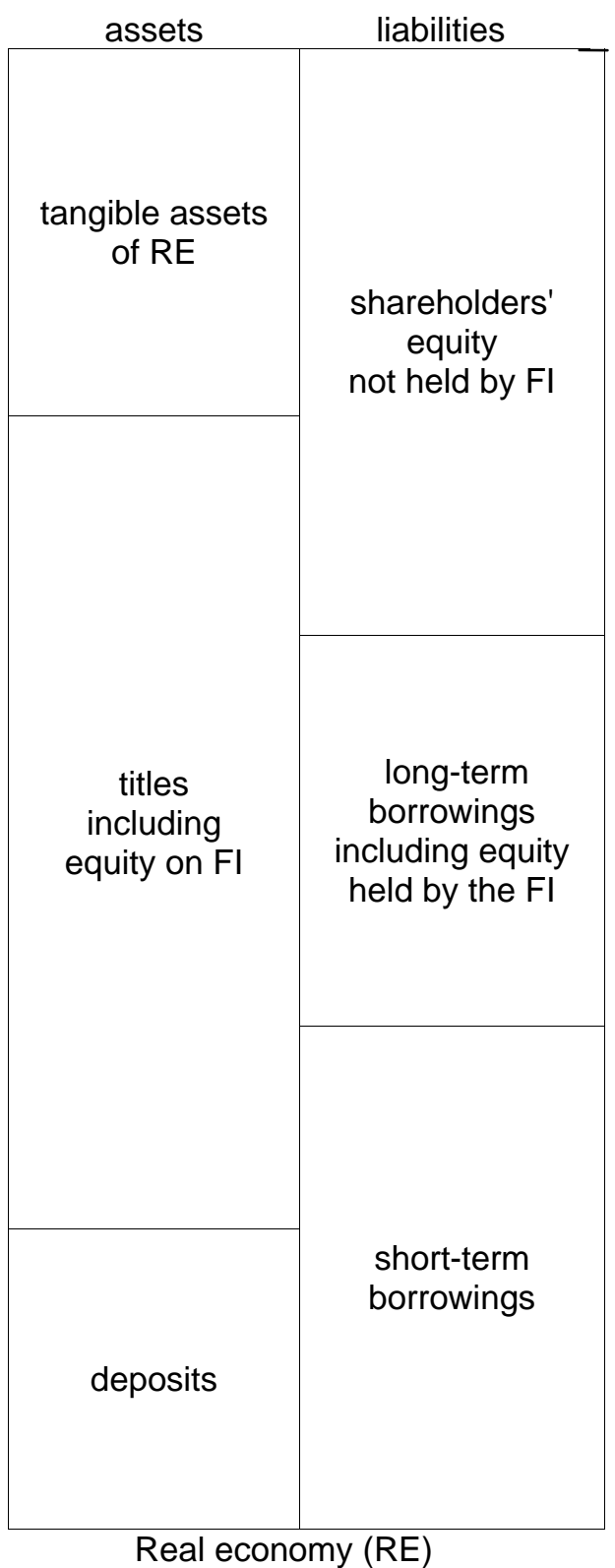

Real economy (RE)

Figure 7 National accounts balance sheet

\begin{tabular}{|c|c|c|c|c|c|c|}
\hline & \multicolumn{3}{|c|}{$\begin{array}{l}\text { French real economy } \\
+ \text { rest of the world } \\
\quad \text { (first sector) }\end{array}$} & \multicolumn{3}{|c|}{$\begin{array}{l}\text { French financial institutions } \\
\text { (second sector) }\end{array}$} \\
\hline & assets & liabilities & balance & assets & liabilities & balance \\
\hline tangible assets & 11901 & & \multirow{3}{*}{-301} & 247 & & \multirow{3}{*}{301} \\
\hline equity & & 11534 & & & 614 & \\
\hline $\begin{array}{l}\text { long-term loans and } \\
\text { borrowings }\end{array}$ & 8992 & 9058 & & 5254 & 5188 & \\
\hline $\begin{array}{l}\text { short-term loans and } \\
\text { borrowings }\end{array}$ & 5879 & 6180 & 301 & 5694 & 5393 & -301 \\
\hline total & 26772 & 26772 & 0 & 11195 & 11195 & 0 \\
\hline
\end{tabular}




\section{World Economic Review}

The fact that we consider all credits as short-term is fully arbitrary and, hence we shall also consider the opposite hypothesis, whereby all credits are long-term. This is shown in Figure 8.

\section{Figure 8 National accounts balance sheet}

\begin{tabular}{|c|c|c|c|c|c|c|}
\hline & \multicolumn{3}{|c|}{$\begin{array}{l}\text { French real economy } \\
+ \text { rest of the world } \\
\quad \text { (first sector) }\end{array}$} & \multicolumn{3}{|c|}{$\begin{array}{l}\text { French financial institutions } \\
\text { (second sector) }\end{array}$} \\
\hline & assets & liabilities & balance & assets & liabilities & balance \\
\hline tangible assets & 11901 & & \multirow{3}{*}{1893} & 247 & & \multirow{3}{*}{-1893} \\
\hline equity & & 11534 & & & 614 & \\
\hline $\begin{array}{l}\text { long-term loans and } \\
\text { borrowings }\end{array}$ & 10367 & 12627 & & 7781 & 5521 & \\
\hline $\begin{array}{l}\text { short-term loans and } \\
\text { borrowings }\end{array}$ & 4504 & 2611 & -1893 & 3167 & 5060 & 1893 \\
\hline total & 26772 & 26772 & 0 & 11195 & 11195 & 0 \\
\hline
\end{tabular}

Whatever the hypothesis we consider, the situations of both sectors are merely mirror opposites, as the short-term and long-term situations of each sector reflect one another. So a "long excess" (i.e. NSFR > 1) for one sector entails a "long deficit" (i.e. NSFR < 1) for the other sector.

Nevertheless the financial sector may improve its NSFR by considering the ASF and RSF factors without implying any change in the NSFR of the real sector. Indeed when a bank improves its ASF factor by considering that a part of its demand deposits is stable, this does not imply anything for the depositors who remain free to withdraw their deposits without notice. And when a bank improves its RSF factor by participating in a market for long-term assets, the legal maturities of the assets remain the same and so is the situation of the debtors. That explains why the financial analysis for industrial firms considers only the legal maturities and has not developed concepts similar to the ASF and RSF factors. Thus the financial situations of both sectors may be non symmetrical.

Therefore the Basel III accords will push the financial institutions, to which deposit banks belong, to use simultaneously four means to improve their NFSR:

i. increasing the legal duration of debts;

ii. decreasing the legal duration of financial assets;

iii. creation of markets to decrease the effective duration of the financial assets by consideration of the RSF factor;

iv. $\quad$ search for more stability in the deposits to increase the ASF factor.

The first two means above will deteriorate the financial situation of the real economy in the same manner that it will improve the state of the financial sector. The third method will increase securitization. The fourth method will include the conversion of deposits into titles, which is the object of the next section.

\section{Where do the capital and other debt titles come from and what are they for, since they are neither for money creation nor to guarantee the deposits?}

We have shown in I that capital is not useful for money creation and cannot be a warranty for the deposits, which are only guaranteed by the reserves of central bank money. Moreover we have shown in II that the excessive quest for capital and of other long-term resources will entail securitization, which is a source of financial crises, and a "bad" financial situation for the real economy.

Therefore, we can wonder if banks' capital has any other purpose than to cover banks' tangible assets, which are very few. To answer this question we must answer the preliminary question: from where do banks' capital and other banks' debt titles come? Indeed at the beginning of the money creation process there is no capital, there are only a loan account and a deposit account which are respectively debited and 
credited of the same amount. Afterwards, as money circulates, the deposit accounts may change from one bank to another within the banking system or take the form of bank notes, but their global volume, when we consider the aggregate of the banking sector, remains equal to the amount of the outstanding loans. And there is not yet any room for capital or debt titles from the banks. If we abstract from the fact that a bank receives interests and commissions, the only way a bank can get capital or debt titles is by selling shares or titles to depositors within the same or at another bank. Thus bank capital and debt titles come from a process of conversion of deposits. Therefore the question of their usefulness is really the question of the utility of this conversion. For an individual bank, it is for fulfilling the Basel accord criteria, i.e. to improve its financial situation, but we have seen that such entails a "bad" financial situation for the real economy and so it seems that conversion of deposits into titles or shares is bad from a macroeconomic point of view.

Another difference between deposits on the one hand and titles and shares on the other is that the former are guaranteed in case of bankruptcy while the latter are not. Hence people who accept that their deposits be converted into titles want some advantages like an interest or a dividend higher than the interest on deposits, or, for the important shareholders, some power in the governance of the bank. The difference between remuneration of titles and interest on deposits must be equal to the premium paid to the guarantee fund or to the F.D.I.C., and thus for the bank the cost of titles and deposits is the same.

It remains that the titles have only two useful purposes: (1) the existence of the shares establishes the obvious fact that banks have owners like industrial firms, which of course is something very important to the shareholders, but may be less important for the economy. (2) As following the Basel criteria, the quantity of loans given by each bank is a multiple of its capital, that determines the quantity of money created by each bank, and therefore the global quantity of money. Thus governments give up any monetary policy for rules, which are international since the big banks are multinational.

Rules constitute the philosophy of the Basel accords: in a free market system, the executive power of the State must not intervene, so there are no monetary policy and no control of the banks. But the experience shows that if the financial sector is completely deregulated, economic crises occur. Hence the market needs rules, which must be written and enacted by the legislative power of the State. The main qualities of rules are that they ought to be simple and permanent, but the Basel accords are quite complex and changed a great deal from Basel I to Basel III, and the further elaboration of Basel III remains unfinished. These rules look partly arbitrary, they have not been elaborated democratically, and they entail dysfunctions in the real economy. Moreover they will be inefficient to prevent systemic crises which can only be remedied by an intervention of the central bank, i.e. an intervention of the executive power, since nobody can ignore that the central bank is a government-owned institution.

These rules allow banks to create all the money they want. First, it is well understood that, contrary to what is taught by the orthodox theory, the central bank cannot control a posteriori the quantity of money created by a bank: once a loan is issued by a bank, the central bank cannot, without provoking a crash, refuse to give bank notes or to transfer the money created to another bank, via the interbank market for funds. Secondly, by converting a part of their deposits into capital, which destroys money, the owners of a bank can always increase their potential of loans, which recreates deposits and then more money than the money just destroyed. Let us set the required coefficient of capital on loans is $r$ Suppose that the shareholders' equity in a given bank is $\mathrm{K}_{0}$

Therefore this bank may issue the quantity of loans and deposits $\mathrm{M}_{0}=\frac{K_{0}}{r}$

The bank's owners can convert the part $\mathrm{X}$ of their own deposits into shares.

Their equity becomes $\mathrm{K}_{1}=\mathrm{K}_{0}+\mathrm{X}$. and they can issue loans and deposits for an amount of

$$
\begin{aligned}
& \mathrm{M}_{1}=\frac{K_{1}}{r}, \\
& \mathrm{M}_{1} \text { being greater than } \mathrm{M}_{0} .
\end{aligned}
$$


By repeating this operation loans and deposits may increase without limit ${ }^{5}$.

This process is not automatic, which means that bank owners are not obliged to increase the volume of net deposits when they convert a part of their deposits into shares, but they may. Indeed they will only do so if they find creditworthy borrowers. As the potential increase of deposits is much larger than the real growth, that may happen only if the borrowers and the bankers anticipate an increase in prices, either of current goods or of assets.

Thus we see that the requirement of a capital ratio cannot be a tool to control the quantity of money, albeit his proponents have not thought about this control but only about the security of deposits. We have already said that capital cannot guarantee deposits and it appears now that bankers can increase bank capital and the quantity of money if higher prices are anticipated. But that will decrease security, since it may be very dangerous if the expectations are not realized. We may consider the recent crisis as an example of unrealized expectations of future houses prices.

\section{Conclusion: Some ideas to reform deposit banks}

We have shown that deposit banks do not need capital, and even capital requirement and high NSFR can lead to a "bad" financial situation for the real sector and to securitization which is another source of dysfunctions. Further the central bank cannot control the quantity of money a posteriori and must guarantee deposits.

Therefore two solutions may be considered:

(i) the "100\% money", which has been suggested by prominent economists (Allais 1977, Fisher 1935) by which money creation is the monopoly of the central bank;

(ii) the solution we prefer: deposit banks retain their ability to create money but this creation is controlled a priori. As they have no capital, or only to the extent they have tangible assets, they have no owners and are controlled by a public agency. As the deposits are guaranteed, they cannot go bankrupt (people would say "they are always saved"), thus they cannot be sanctioned, but a disciplinary board should be instituted to sanction their employees when they violate a regulation.

We must answer the question: how much money must be created and to whom must it be lent? To some this question may imply that money is exogenous to the system of production and that its quantity is controlled by the central bank as, for example, for the monetarists, by means of the deposit multiplier, or for the "100\% money" theorists, for the fact that only the central bank creates money.

Both theories leave to the market the question of "to whom must it be lent?", which means that money is lent to the most profitable activities, with this process determining the bank rate of interest. But experience shows that the most profitable activities may be only speculative and not productive. PostKeynesian theory shows that money is endogenous, i.e. its quantity is not determined ex ante (i.e. before the production) globally by the sole monetary institutions, but at the beginning of each act of production in an exchange between the industrial firm and its bank. In fact for Post-Keynesian theory there is no conscious determination of a global quantity of money, this quantity being the result of individual borrowings from banks in order to finance production. Therefore the problem is not to determine the "good" quantity of money, but to verify that each act of marketable production may be financed by an adequate creation of money and that each act of money creation finances a marketable production and nothing else as a speculative operation. Hence it is necessary to separate deposit banks, which create money, from other financial institutions, with access to credits of the central bank being reserved to the deposit banks and to government. Further the monetary circuit theory (Vallageas 2013, chapter 6) shows that monetary creation is at least equal to the flow of incomes paid for the production of all goods and services, either for consumption or investment purposes. In order to prevent money creation for speculative purposes, we suggest that deposit banks finance only

5 From the idea that Monetary Authorities cannot control the quantity of money through the control of bank capital, Werner $(2010 a, b)$ concludes that they must use other control means. He quotes Wicksell (1907) to affirm that this control through bank capital is unfeasible. 


\section{World Economic Review}

those incomes and that they be obliged to finance all of them, the only condition being that the production be marketable ${ }^{6}$. Speculative activities and the purchase of investment goods (not to be confused with their production) would be financed by other financial institutions, if necessary. Therefore all the marketable production would be financed, which would lead to full employment. If we abstract from the costs of running banking institutions, that should be reimbursed, and following a suggestion of the Kansas City School (Forstater and Mosler 2004), bank interest would be zero, since it would not be necessary to limit production to a predetermined quantity of money, thereby eliminating the projects whose profitability would be less than the rate of interest.

The regulations that we propose will be certainly understood by some readers as a breach of the liberty of trade. But deposit banks are not industrial firms, since the former have the privilege to access central bank credits and to create money. Thus, as a counterpart of this privilege, they must work for the interest of society. Indeed liberty of trade means liberty to finance for any marketable production project and the reform we propose would guarantee this liberty.

\section{References}

Allais, M., 1977. L'impôt sur le capital et la réforme monétaire. Paris: Hermann.

Bardoloi, S., 2003. Basel II: New Wine in an Old Bottle. Risk World. [on line] Knoxville, TN: Tec-Com Inc. Available at: < http://www.riskworld.com/news/03q2/nw03a103.htm> [Accessed 1 June 2011].

Bank of International Settlements (BIS), 1998. The Basel Capital Accord, International Measurement of Capital Convergence and Capital Standards (July 1988, updated to April 1988) [on line] Available at: $<$ http://www.bis.org/publ/bcbsc111.pdf $>$ [Accessed 1 June 2011].

BIS, 2004. International Convergence of Capital Measurement and Capital Standard. A Revised Framework. June 2004 [on line] Available at: <http://www.bis.org/publ/bcbs107.pdf> [Accessed 1 June 2011].

BIS, 2009a. History of the Basel Committee and its Membership (August 2009) [on line] Available at: $<$ http://www.bis.org/bcbs/history.pdf> [Accessed 1 June 2011].

BIS, 2009b. Comprehensive response to the global financial crisis (September 7, 2009) [on line] Available at: < http://www.bis.org/press/p090907.htm> [Accessed 1 June 2011].

BIS, 2009c. Strengthening the resilience of the banking sector (December 2009) [on line] Available at:

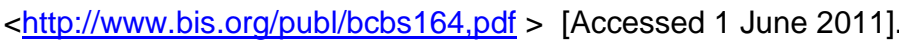

BIS, 2009d. International framework for liquidity risk measurement, standard and monitoring (December 2009) [on line] Available at: < http://www.bis.org/publ/bcbs165.pdf > [Accessed 1 June 2011].

BIS, 2010a. Basel III: International framework for liquidity Risk measurement, standard and monitoring (December 2010, http://www.bis.org/publ/bcbs188.pdf > [Accessed 1 June 2011].

BIS, 2010b. Basel III: A global regulatory framework for more resilient banks and banking systems (December 2010) [on line] Available at: < http://www.bis.org/publ/bcbs189.pdf > [Accessed 1 June 2011].

BIS, 2010c. Comments received on the consultative documents "Strengthening the resilience of the banking sector" and "International framework for liquidity risk measurement, standard and monitoring" (December 2010) [on line] Available at: < http://www.bis.org/publ/bcbs165/cacomments.htm > [Accessed 1 June 2011].

Forstater, M. and Mosler, W., 2004. The Natural Rate of Interest is Zero (Working Paper No 37, December 2004). Kansas City, MO: University of Missouri [on line] Available at: < http://www.cfeps.org/pubs/wppdf/WP37-MoslerForstater.pdf> [Accessed 1 June 2011].

\footnotetext{
${ }^{6}$ Werner $(2010 \mathrm{a}, \mathrm{b})$ agrees with Post-Keynesians that money is created by banks and that it should be created only for productive purposes. Therefore he concludes that an a priori control should be instituted or re-instituted, and he cites countries (Werner 1997, 2002, 2005), as Japan, where this control exists. Nevertheless he keeps the idea that Monetary Authorities should control a priori both the quantity of money and its distribution between productive activities, i. e. in fact marketable activities.
} 


\section{World Economic Review}

Fisher, I., 1935. 100\% money; designed to keep checking banks 100\% liquid; to prevent inflation and deflation; largely to cure or prevent depressions; and to wipe out much of the national debt. New-York: Adelphi Institut National de la Statistique et des Etudes Economiques, 2011. Tableau Economique d'Ensemble au 31 décembre 2009 [on line] Available at: <http://www.insee.fr/fr/themes/comptes-

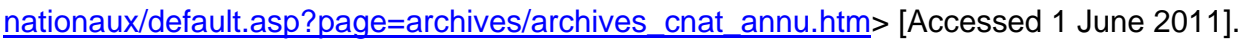

Minsky, H. P., 1982. Can "It" Happen Again?: Essays on instability and finance. Armonk, NY: M. E. Sharpe. Toporowski, Jan, 2009, "Enforced Indebtedness" And Capital Adequacy Requirements (Policy Note, 2009/7, May 2009). Annandale-on-Hudson, NY: The Levy Economic Institute of Bard College: [on line] Available at: $<$ http://www.levyinstitute.org/pubs/pn 09 07.pdf $>$ [Accessed 1 June 2011].

Vallageas, B., 2009. Analyse de la crise financière actuelle. Où vont-ils chercher ces milliards qu'ils n'ont pas? Comment l'Etat assureur en dernier ressort permet d'accéder à la Banque Centrale Européenne, prêteur en dernier ressort, Revue de la Régulation [on line] Available at: < http://regulation.revues.org/index7544.html> [Accessed 1 June 2011].

Vallageas, B, 2013. Monnaie, Profit et Valeur. Un essai sur le circuit, l'économie monétaire de production et sur les liens entre la macroéconomie et l'analyse financière des entreprises. Forthcoming.

Werner R. A., 1997. 'Towards a new monetary paradigm: a quantity theorem of disaggregated credit', with evidence from Japan. Kredit und Kapital, Duncker and Humblot, Berlin, 30, pp. 276-309.

Werner, R. A., 2002. Monetary policy implementation in Japan; what they say vs.what they do, Asian Economic Journal, 16, pp.111-51

Werner, R. A., 2005. New Paradigm in Macroeconomics: Solving the Puzzle of Japanese Macroeconomic Performance, UK : Basingstoke: Palgrave Macmillan

Werner, R. A., 2010a. Comment received on the consultative document: Strengthening the Resilience of the Banking Sector (Bank of International Settlements, April 16, 2010): [on line] Available at: http://www.bis.org/publ/bcbs165/universityofsou.pdf [Accessed 1 November 2012].

Werner, R. A., 2010b. Towards Stable and Competitive Banking in the U.K. - Evidence for the ICB (Centre for Banking, Finance and Sustainable Development, Policy Discussion Paper No 3/1 - 10, November 15, 2010). University of Southampton, UK: [on line] Available at: http://eprints.soton.ac.uk/342277/1/Werner Soton Towards Stable Banking 201011.pdf [Accessed 1 November 2012].

Wicksell, K., 1907. The influence of the rate of interest on prices, Economic Journal, 17, pp.213-20.

Wray, L. R., 2006. Can Basel II Enhance Financial Stability? A Pessimistic View (Public Policy Brief, Highlights $N^{\circ}$ 84A, May 2006). Annandale-on-Hudson, NY: The Levy Economic Institute of Bard College: [on line] Available at: <http://www.levyinstitute.org/pubs/hili 84a.pdf> [Accessed 1 June 2011]. 